\title{
Motiv tabuizovaného jména v prozaickém folkloru. Český materiál v evropském kontextu
}

\author{
Adéla Adámková \\ DOI: 10.21104/CL.2021.1.04 \\ The Motif of Name Taboo in Prose Folklore. \\ Czech Material in European Context
}

\begin{abstract}
The study is focused on the motif of name taboo in European prose folklore (mostly focused on Czech folklore tradition). This taboo can be defined as a prohibition against uttering the name of a person or thing. The motif appears in folklore in several variants. This taboo may refer to the uttering of one's own name or the name of dangerous being. The study examines the differences and similarities between the various forms of motifs and compares changes in its narrative and social functions over time.
\end{abstract}

Key words

name taboo, taboo, prose folklore, czech folklore

\section{Contact}

Mgr. Adéla Adámková, Ústav etnologie, Filozofická fakulta, Univerzita Karlova, Celetná 20, 11000 Praha 1, Czech Republic; e-mail: adadaq@ seznam.cz

Jak citovat / How to cite

Adámková, Adéla. 2021. Motiv tabuizovaného jména v prozaickém folkloru. Český materiál v evropském kontextu. Český lid 108, 67-81. https://doi.org/10.21104/CL.2021.1.04 


\section{Úvod}

Předmětem studie je motiv tabuizovaného jména a popis jeho výskytu a funkcí v evropském, a především českém folklorním materiálu. Text dále rozebírá také proměny motivu a jeho funkcí v populární kultuře. Koncept tabuizovaného jména se vyskytuje jako předmět studia v několika vědních oborech a má více odborných uchopení (ta budou představena dále). Základní definice mluví o tomto fenoménu jako o zákazu vyslovení jména osoby, př́padně předmětu (ve folkloristice např. Thompsonův motiv ${ }^{1} \mathrm{C} 430$ Name tabu: prohibition against uttering the name of a person or thing).

Samotný koncept tabu má v prostředí folklorních vyprávění jistá specifika. Tabu lze obecně definovat jako implicitní zákaz, na jehož dodržování dohlíží nadpřirozené síly (božstva či démonické bytosti), které automaticky trestají jeho porušení (Röhrich 1976: 127). Porušení tabu není nutně morálně špatné, primárně je definováno jako nebezpečné (Frazer 1994: 201). Často představuje konflikt mezi pudem a zákazem a ti, kteří podle něj žijí, k němu mají ambivalentní vztah (Freud 1991: 29). Tabu náleží vždy do určitého kontextu: jsou podmíněna historicky, geograficky, sociálně či kulturně (Kraft 2006: 10). Některé z těchto charakteristik se postupem času mění (v dnešní době je tabu sekularizované a racionalizované), rovněž mají některá tabu časem tendenci ztrácet svůj vliv či platnost - v evropské tradici typicky taková, jež byla spojena s křestanskou vírou (Röhrich 1976: 127). V tradičním folklorním materiálu se objevují tabu, jež jsou platná v sociální realitě a jež jsou často univerzální (např. kanibalismus, incestní tabu či vražda). Dále také tabu spojená s křestanskou a lidovou vírou. Lze ovšem narazit také na motivy, jež se v sociální realitě zpravidla nenachází (např. tabu ohlédnout se či tabu promluvit). Jsou to převážně motivy, které mají čistě narativní funkci a jejich úkolem je pouze vyvolání napětí ve vyprávění. Objevují se pouze tam, kde jsou následně porušeny (Röhrich 1976: 128). Často se překrývají s tím, co jsou dle Proppova rozboru pohádky její druhá a třetí funkce - zákaz a porušení zákazu (Propp 1999: 32-33). Tuto funkci však mohou mít rovněž první zmíněné motivy tabu, a pochopitelně také diskutovaný motiv tabuizovaného jména. Posledním specifikem tabu ve folklorních vyprávěních je skutečnost, že se velmi často týkají konkrétních démonických bytostí, a v př́iběhu dochází $\mathrm{k}$ př́mé konfrontaci s těmito bytostmi (na rozdíl od sociální reality, kde se nadpřirozené síly v empiricky zaznamenatelné formě neobjevují).

Vrátíme-li se k motivu tabuizovaného jména, jeho porušení může být vědomé i nevědomé a vyvolává nepř́íjemnou událost, kterou je ve folklorních vyprávěních velmi často přivolání jmenované bytosti, jež je nějakým

1 Všechny odkazy na Thompsonův motivický katalog viz Thompson 1955. 
způsobem nebezpečná. Je-li však tabuizace vztažena na lidskou postavu, může být účelem zákazu vyslovení jména ochrana dané osoby. Tato funkce tabu je velmi často součástí archaických náboženství a častěji než ve folkloru na ni lze narazit v každodenním životě konkrétních sociálních či etnických skupin (viz dále).

Materiál prezentovaný $\mathrm{v}$ této studii je zaměřen na prostředí evropského folkloru s důrazem na českou folklorní tradici. Byl nashromážděn v průběhu výzkumu sbírek a pramenů mapujících prozaická folklorní vyprávění na českém území od poloviny 19 . století po současnost. ${ }^{2}$

Cílem studie je poukázat na podobnosti a rozdíly mezi jednotlivými variantami motivu a popsat narativní a sociální proměny motivu v čase a prostoru. Činí tak popisem zmíněného českého folklorního materiálu, který zasazuje do evropského kontextu. Základní př́íklady z evropského prostředí jsou uvedeny ty, na něž odkazuje v mezinárodním katalogu folklorních motivů Stith Thompson, př́padně jsou to takové narativy, které se v obdobné či velmi podobné formě nachází také ve více rozebíraném českém kontextu.

Úkolem studie je zodpovědět otázky, v jakém typu vyprávění a v jakém kontextu se motiv typicky vyskytuje a jakou transformací prošel motiv a struktura typických vyprávění s ním spojených v průběhu času. Současně se také zabývá tím, jaké narativní a sociokulturní funkce plní. Pracuje $\mathrm{s}$ hypotézou, že funkce a charakter motivu se v čase mění v návaznosti na změnách v sociokulturním kontextu, a liší se tedy ve folkloru tradičním a současném.

\section{Magie slova a magie jména}

Koncept tabuizovaného jména je nutně spojen s vírou $\mathrm{v}$ jeho magické vlastnosti. Je proto nutné ho alespoň stručně představit. Původ magie jména je často hledán v náboženstvích archaických společností, v nichž se objevuje víra $\mathrm{v}$ podobě fetišismu, šamanismu či obecně víra $\mathrm{v}$ magii. Zde také lze narazit na pojetí jména jako fyzické součásti člověka. Vyslovením jména je možné dané osobě ublížit, napadnout ji prostřednictvím magie, a je proto nutné své jméno skrývat (Clodd 1898: 53-54).

Protože často existovalo velké množství jmen, jež nesměla být vyslovena, a většina $\mathrm{z}$ nich byla také označením pro každodenně používané předměty, vznikalo mnoho zástupných pojmenování, a docházelo tak k velmi rych-

2 Jednalo se o výzkum pro mou bakalářskou práci, která se věnuje tabuizovanému jménu v českém folkloru, a částečně také o rozšířenější výzkum pramenů pro mou diplomovou práci, jež se zabývá celkovým výskytem tabu v českém prozaickém folkloru. 
lým proměnám v jazyce (Frazer 1994: 223-224). Jazyková tabu obecně lze pravděpodobně nalézt již u starověkých lovců, u nichž byla součástí lovecké magie. Jsou založena na představě, že zvířata rozumí lidskému jazyku. Byla zavedena pro pojmenování lovných zviŕăat a zviřat člověku nebezpečných (typicky medvěd, vlk). U lovných zviřat byl důvod takový, aby se dané zvíře vyslovením jména nevyplašilo, v př́padě zviŕat nebezpečných to byl strach z jejich přivolání, který dal vzniknout zákazu vyslovení jejich jména (Röhrich 1976: 129).

Víra v magii slova je vlastní také tradičním společnostem evropským. I v evropských jazycích byla jazyková tabu př́čcinou zániku slov, která byla bud' zcela vypuštěna, nebo byla nahrazována zástupnými výrazy (ty mohou mít podobu eufemismů, metafor apod.). Jazyková tabu mají charakter archaický nebo společenský. Archaická tabu jsou spojena s lidovou vírou a folklorem. Bylo zapovězeno vyslovit jména démonických postav, aby nebyly přivolány apod. Společenská tabu zapovídají vyslovit slova společensky nepřijatelná (vulgarismy, slova porušující politickou či jinou korektnost apod.). Tato tabu vznikají rovněž v současné době (Janyšková 2017).

Britský antropolog James George Frazer ve své klasifikaci řadí do tabuizovaných slov osobní jména, jména př́buzných, jména mrtvých, jména králů a dalších posvátných osob, ale také jména bohů. V souvislosti s nutností jméno skrývat se v každodenním životě konkrétních etnických skupin objevovaly nejrůznější př́edpisy a pravidla o zatajování jména. Ty mají mnoho podob. V př́padě osobních jmen se objevuje např́klad pravidlo, které zapovídá vyslovit vlastní jméno, a má představovat ochranu před čaroději, jimž znalost jména umožňuje dané osobě ublížit (etnické skupiny střední Austrálie); pravidlo, dle něhož nesmí vyslovit své jméno pouze daná osoba, je však možné, aby to za ni učinil někdo jiný (etnické skupiny Britské Kolumbie, východní Indie, jižní Afriky); nebo pravidlo, které zakazuje vyslovit jméno pouze v určité situaci, např́ḱlad jsou-li válečníci na loupežné výpravě (africké etnikum Nandi). Jména př́ibuzných, králů a posvátných osob a také bohů bylo zapovězeno vyslovit ze stejného důvodu jako jména vlastní: aby nemohli být napadeni prostřednictvím magie. Zákaz vyslovení jména zemřelého je obvykle spojen s vírou, že vyslovením jména je možné přivolat ducha zemřelého. Je to jev velmi univerzální, byl zaznamenán na Sibiři, v jižní Indii, Mongolsku, Africe, na Borneu atd. (Frazer 1994: 219-233).

Magické vlastnosti jazyka se dodnes odráží ve folkloru. Jsou to různá zaklínadla či prokletí, která se vyplní. Př́íkladem takového vyprávění je pohádkový typ $\mathrm{ATU}^{3} 451$ The Maiden Who Seeks Her Brothers. U nás je

3 Všechny odkazy na typologii ATU viz Uther 2004. 
pohádka nejčastěji známa pod názvem Sedm krkavců. V této pohádce matka v rozčilení zaklela, aby se z jejích neposlušných synů stali krkavci/havrani. Tak se opravdu stane a bratři musí být následně vysvobozeni vlastní sestrou (Jech č. 49A+49B 1959: 121-123; Polívka č. 3 1916: 15-17; Dvořák č. 23 1984: 92-95; Němcová II 1950: 165-177). Stejně tak se vyplní, prohlásí-li někdo, at' se propadne do země / at' ho odnesou čerti, pokud lže (Kulda č. 861963 : 316-317; Röhrich 1966: 19).

\section{Motiv tabuizovaného jména ve folkloru}

Jak již bylo naznačeno, tabuizované jméno v sociální realitě, jehož podoba se nejdéle zachovala, ačkoli ne v evropském prostředí, má v první řadě funkci ochrannou a zapovídá vyslovit jméno zranitelné osoby. Tabuizované jméno ve folklorních vyprávěních se častěji objevuje v rozdílné variantě, kdy je zapovězené vyslovit jméno nebezpečné bytosti, protože je tímto způsobem zpravidla přivolána. Tento motiv je však znám také z lidové víry.

Motiv tabuizovaného jména je $\mathrm{v}$ této studii rozdělen na základě několika nejčastějších variant, v nichž se ve folklorním materiálu vyskytuje. První variantou je nejfrekventovanější tabuizované jméno nebezpečné bytosti. Je zde rozveden především motiv čerta či jiné démonické bytosti coby přivolaného tanečníka/partnera. Dále je zmiňován motiv vyslovení jména, které je chápáno jako urážka. Tento motiv je v českém folkloru spojen s postavou Krakonoše. Objevuje se také motiv přivolání vlka, dalšího druhu nebezpečného tvora, na nějž se může tabuizace vztahovat. Jako poslední jsou rozvedena současná vyprávění o vyvolávání duchů. Druhá podoba tabuizovaného jména, reprezentována pohádkovým typem ATU 500, jenž zahrnuje uhodnutí jména nebezpečné bytosti, se objevuje ve folklorním repertoáru minimálně severozápadní a střední Evropy. Třetí variantou tabuizovaného jména je zákaz prozrazení jména nadpřirozené či zakleté manželky. Poslední podobou motivu je skrývání vlastní identity, jež je v evropském prostředí možné nalézt zejména ve vyprávěních mytologických. U jednotlivých motivů je vždy uveden odkaz na jejich výskyt v mezinárodním katalogu folklorních motivů Stitha Thompsona a, je-li to možné, také jejich pohádkový typ.

\section{Přivolání nebezpečné bytosti vyslovením jejího jména}

Nejčastěji se vyskytující podobou tabuizovaného jména a ve folklorním materiálu hlavním důvodem, proč k tabuizaci dochází, je přivolání nebezpečné bytosti jejím jmenováním. V Thompsonově klasifikaci jsou to motivy C432. Tabu: uttering name of supernatural creature a C433. Tabu: 
uttering name of malevolent creature. Taková bytost (nejčastěji je to bytost démonická, mohou se však objevit také jiná nebezpečné stvoření, např́íklad zvírata) zpravidla ohrožuje toho, kdo ji přivolal, případně přímo splní přání, které ve spojení s ní dotyčný nepromyšleně vyslovil.

V evropském prostředí se takový motiv nachází např́íklad v islandské pověsti o dívce, která při rozhovoru o elfech prohlásila, že by se za jednoho klidně vdala. Po nějaké době elf opravdu přišel a dívku s sebou odvedl (Árnason 2008: 61-62).

Typicky se motiv objevuje ve spojení s pohádkovým typem ATU 1164 The Devil and the Evil Woman. Vyprávění je proslavené především Machiavelliho novelou Belfagor, jeho původ je však folklorní. Vystupuje v něm dábel, který se oženil s lidskou ženou, před níž brzy utekl. Schoval se u sedláka, jemuž později pomohl k bohatství tím způsobem, že vždy posedl bohatou dívku a sedlák ji následně vyléčil. Jednoho dne čert odmítl opustit královskou dceru, sedlák ho ale donutil k útěku zmínkou o jeho ženě (Tille I 1929: 87-88). Podobně se vyprávění objevuje také ve folklorním materiálu, bývá však často doplněné dalšími motivy. V českém prostředí je jeho nejznámějším zpracováním pohádka Čert a Káča Boženy Němcové. Pohádka vypráví o neoblíbené dívce, s níž nikdo nechtěl jít tancovat.

„Jedenkráte jde také a myslí si po cestě,Tak starájsem již, a ještějjem s hochem netancovala, neni-li to $k$ zlosti? Vèru dnes bych tancovala třeba šcertem'. Se zlostí príjde do hospody... Najednou vejde do dveř́ pán v mysliveckém oděvu. " (Němcová I 1950: 240)

Čert s ní v této podobě tančil, následně se ho ale nepřestala držet a musel ji nosit na zádech. Zbytek vyprávění odpovídá předchozímu popsanému (Němcová I 1950: 240-246; srov. Polívka č. 51 1916: 130-131; Kubín Kl. II č. 25 1910: 97-98; Zíbrt 1924: 362-367).

Motiv přivolání čerta nebo jiné démonické bytosti coby tanečníka je velmi častý zejména $\mathrm{v}$ prostředí českých pověstí. Zde ovšem nabývá podoby, která se blíží spíše prvnímu uvedenému př́kladu pověsti islandské. Na rozdíl od pohádkového typu ATU 1164 tu již nevystupuje čert, který se chce zbavit ženy, ale naopak žena, jež se nemůže zbavit svého nápadníka. Pověsti popisují dívku, o kterou neměl nikdo zájem, a ona jednoho dne prohlásila, že by chtěla i čerta / šla by tančit i s čertem. Čert se následně objevil a o dívku se ucházel. Ve vyprávění z Rožnovska musela dívka vymyslet řadu úkolů, aby se čerta následně zbavila (Kulda č. 15 1963: 59-61). V pověsti východočeské čert dívku na konci večera, kdy spolu tančili, odvedl s sebou (Hošek 1897: 186-187). 
Ve stejné roli jako čert se v českých pověstech velmi často objevuje také vodník. V podkrkonošské pověsti zoufalá dívka přivolala vodníka k tanci:

„Fedna holka šla k muzice, byla tam kůpa kamarádek, tak vidèla, že tancovat moc nebude. A že byla na tanec jako drak, povudá jim: ,Holky, já dybych mèla dnes hastrmanem tancovat, tak musim!" Všecky se tam nahrnuli, a najednou takovej hošik mladej príde pro ni a jen to s ní fofruje. Už druhej, tréeti kousek a pořád s ní. Ty se ji smály: ,Kohos to naplašila! Má mokrý límečky u ruky. “ (Kubín Podk. I č. 159 1964: 295)

Dívce poté dělá značné potíže vodníkovi utéct (Koštál 1892: 469; Kubín Podk. I č. 159 1964: 295), v jiném vyprávění musela dívka učinit opatření (vykoupat se v odvaru z bylin), aby se ho zbavila (Dvořák č. 72N 1984: 269-270). Mírně odlišná je západočeská pověst, v níž matka proklela dceru, aby si ji vzal vodník, když šla i přes zákaz k muzice. Vodník s dívkou tančil a následně ji odvedl (Koštál 1892: 469-470). V moravském vyprávění se na pozici přivolaného nápadníka objevuje duch, kterého dívka přivolala. Duch přišel a dívka brzy na to zemřela (Sirovátka 1959: 104-107). Na těchto př́kladech lze pozorovat, že přivolání bytosti ženě vždy působí nepř́ijemnosti, někdy dokonce až smrt. Zmiňovaný čert mohl být přivolán také z jiných důvodů, velmi často lze narazit na klení jeho jménem (ve smyslu ulevení si ve stavu emocionálního vypětí použitím tabuizovaného slova či fráze). Ve vyprávění z Kladska zakleje sedlák, kterému se nedařila práce: „Dyby u sta hromu čert už na tole přišel!“ A během chvíle se čert objevil (Kubín Kl. I č. 16 1908: 37-38; srov. Kulda č. 46 1963: 193; Grohmann č. 270 2009: 199). Pokud je tímto způsobem čert přivolán, protože se mu daná osoba posmívala nebo ho urážela, často ji fyzicky napadl nebo rovnou odvedl (Sosnovec 1910: 419; Hazuka - Řepa 1896: 237; Kubín Podk. II č. 31 1971: 56).

Démonickou bytostí, jež přivolá vyslovení jejího jména, protože pro ni často znamená urážku, je Krakonoš. Krakonoš je jednou z mála postav české démonologie, která má vlastní jméno, a jde o jednu konkrétní postavu (ojediněle mohl mít vlastní jméno také vodník). Dnes je nejčastěji označován českou variantou jména, ale používalo se i mnoho podob jeho varianty německé - Rýbrcoul, Líbrcoul apod. Jméno Krakonoš se v českém prostředí ujalo až ve 20 . letech 19 . století, do té doby se nejvíce používalo právě různých podob německého Rübezahl. Ve stejné době jako jméno Krakonoš se objevil také Řepočet, doslovný překlad jména německého, který se ale v českém prostředí neujal (na rozdíl od polského Liczyrzepa) (Jech 2008: 9-10). 
V některých pověstech se objevuje dobová snaha demonstrovat Krakonoše jako bytost českou. Zde ho uráží, používá-li se německých variant jeho jména. Kladská pověst vypráví, jak Krakonoš unesl princeznu, ale protože u něj byla neštastná, snažil se ji potěšit tím, že jí nosil řepu, z níž si mohla princezna vyčarovat společnost. Jednoho dne od Krakonoše utekla, a když se dostala z dosahu jeho moci, vysmívala se mu jménem „Rübezahl“. Lidé začali následně používat jméno v domnění, že je správné (Jech č. 5 1959: 30-32). Za použití jména Rýbrcoul se Krakonoš mstí také v podkrkonošských pověstech:

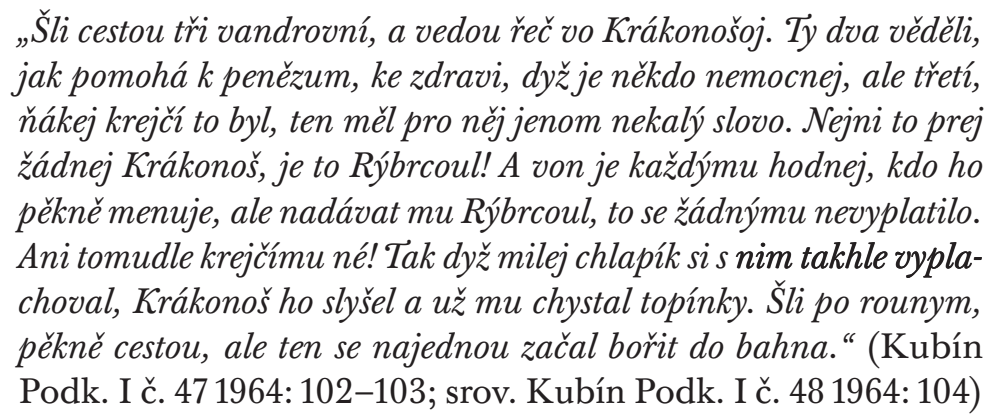

Lze ovšem narazit také na pověsti, v nichž reaguje nepříznivě i na použití jména Krakonoš (Jech 1961 In Jech 2008: 357; Večerník 1957 In Jech 2008: 362). Krakonoš mohl být přivolán vyslovením jeho jména rovněž bez toho, aby se jednalo o explicitní urážku. Tak se stalo v kladském vyprávění o ženě, jež nedokázala utišit své dítě, a tak jako výhružku řekla: „Krakonoši, pod, pod, sežer ho!“ Krakonoše tak přivolala a ten si chtěl dítě odnést (tento motiv je dobře znám z Erbenovy balady Polednice) (Jech č. 50 1959: 123-125).

Jiným typem bytosti, jež může být vyslovením jména přivolána, je nebezpečné zvíře (Thompson C433.2. Dangerous animals not to be named). V českém folkloru je to nejčastěji vlk. Přivolání vlka se objevuje ve vyprávění podobnému předchozí pověsti o Krakonoši. Matku trápilo její dítě a pohrozila mu tím, že pokud nepřestane, vystrčí ho za dveře, kde čeká vlk. Shodou okolností šel vlk právě kolem a matčina slova zaslechl (Dvořák 2001: 31; Dvořák č. 5336* 2016: 267). Toto vyprávění nejlépe charakterizuje př́sloví „My o vlku a vlk za dveřmi“.

Dalším typem bytostí, které mohou být přivolány vyslovením jména, jsou duchové mrtvých. Na vyvolávání duchů, s nímž se tento motiv obvykle pojí, lze narazit častěji v pověstech současných. Jejich vyšší obliba v současné době je pravděpodobně způsobena vlivem sekularizace. Vyvolávání duchů je spojené především s prostředím dětských táborů, může to ovšem být také zábava dospělých. Má-li ústní podobu, zahrnuje vyslovení jména vyvolávaného 
(výjimkou je např. Hagen v lomu Amerika, který se zpravidla ukáže, udeř́li někdo do kolejnice [Janeček 2007: 57-59]). V českém prostředí se obecně objevuje okruh osobností, jež jsou nejčastěji vyvolávány. Z těch historických je to např́klad Božena Němcová nebo Adolf Hitler. Důsledky jejich přivolání se projevují jako zvláštní fyzikální jevy (výpadky elektřiny), může však také dojít př́mo $\mathrm{k}$ fyzickému napadení samotným duchem (napadení nejčastěji skončí se škrábanci nebo modřinami) (Janeček 2015: 77-89). Vyvoláváni jsou ale také duchové, jejichž předchozí existence je fiktivní, př́ípadně má velké množství neprokazatelných variant. Takovou nejznámější postavou je mezinárodně rozšířená Bloody Mary (u nás známá jako Krvavá Mary/Máŕí). Ta se zpravidla ukáže, když si člověk stoupne o půlnoci před zrcadlo a třikrát řekne její jméno (existuje však mnoho dalších podobných variant způsobu přivolání). Poté, co se objeví, dotyčného obvykle fyzicky napadne (vyškrábe mu oči). V českém prostředí byla pověst zaznamenaná např́klad takto:

„Když půjdeš v noci se svićkou $k$ zrcadlu a trìkrát před ním řekneš ,Krvavá Máry', tak se ráno probudís a budeš poškrábaná do krve po celym těle. Taky ti bude týct krev z nosu. "(Janeček 2015: 101)

Pověst o Bloody Mary byla poprvé zaznamenána v 70. letech minulého století v USA, rozšíríla se však do celého světa. Variant, kdo byla Mary jako živá, je nesčetné množství, od obyčejné dívky, přes čarodějnici, až k Panně Marii (Janeček 2015: 101-108).

Na zmíněných př́kladech lze pozorovat, že narativní funkce motivu se mění. Ve folkloru tradičním je jméno vysloveno spíše jako součást pohrůžky nebo přání, často bez toho, aby dotyčný skutečně věril či doufal, že přivolaná bytost skutečně přijde. Současné pověsti na druhé straně přímo poskytují návod, jak bytost přivolat, a lidé v nich tak činí s vědomím, že je přivolaná bytost s největší pravděpodobností napadne, či se je přímo pokusí zabít. Podstatným rysem pověstí současných, který ve vyprávěních tradičních zcela absentuje, je dobrovolné prožívání emoce strachu, jež se s fenoménem vyvolávání duchů pojí.

\section{Uhodnutí jména nebezpečné bytosti}

Tento motiv se typicky objevuje $\mathrm{v}$ mezinárodním pohádkovém typu ATU 500 The Name of the Supernatural Helper, v Thompsonově klasifikaci odpovídá motivu C432.1. Guessing name of supernatural creature gives power over him. Tento typ vyprávění byl zaznamenán v různých obměnách ve folklorní tradici britských ostrovů, kontinentální západní Evropy, ale také v českém prostředí. 
Tradiční podoba vyprávění se nachází ve sbírce J. a W. Grimma Kinderund Hausmärchen. Pohádka vypráví o chudé dívce, s níž se oženil král, když za pomoci mužíka, jemuž za jeho služby slíbila prvorozené dítě, dokázala, že dokáže upříst slámu ve zlato. Mužík se rozhodl dívce dítě nechat, pokud dokáže uhodnout jeho jméno. To se dívka dozvěděla díky štastné náhodě, protože královnin sluha slyšel mužíka si v lese prozpěvovat, že dostane královnino dítě, protože nikdo netuší, že se jmenuje Rumpelstilzchen. Když se posledního večera mužík ukázal, dívka jeho jméno uhodla a on zmizel (Grimm 1812: 253-255).

Dalších několik variant této pohádky převážně z území Velké Británie zaznamenává ve své knize Tom Tit Tot: An Essay on Savage Philosophy on Folk-tale britský antropolog Edward Clodd (Clodd 1898). Vychází z verze pohádky z východní Anglie. Ta se od předchozí liší tím, že do mužíkovy moci měla upadnout sama dívka, pokud se jí nepodaří jméno uhodnout. Jeho jméno Tom Tit Tot však bylo podobným způsobem odhaleno a mužík na konci zmizí (Clodd 1898: 8-16). V českém prostředí byla pohádka zaznamenaná v několika variantách. Kladská pohádka přesně odpovídá první popsané variantě, s jediným rozdílem, že když královna nakonec uhodla jméno, mužík dupl do podlahy tak silně, až se roztrhl na dvě části (Jech č. 81 1959: 187-189). V tomto případě pohádka přímo vychází z verze německé (se stejným závěrem byla zaznamenaná ve druhém vydání Kinder- und Hausmärchen), a stejně jako v pohádce německé se jmenuje Rumpelstilzchen a písnička, již si mužík prozpěvuje, je v němčině: „Heute back ich, morgen brau ich, Übermorgen hol ich's Königinkind. Gut, dass neimand weiss, Dass ich Rumpelstilzchen heiss." (Jech 1959: 189)

Lze ovšem narazit také na variantu, jež se více podobá té anglické. Liší se pouze v drobnostech: dívka zde přede len a postava, která jí pomůže, je popsána konkrétně jako trpaslík (v anglické verzi je to malá černá bytost s dlouhým ocasem) (Stránecká In Tille II/2 1937: 129-130). V této pohádce je trpaslíkovo jméno již počeštěné, jeho písnička zní: „Zjitra princa mám, raduju se sám. Tingltangl jméno mé, královně nevědomé: Kdyby ona věděla, což by byla veselá. Zjitra princa mám, raduju se sám." (Stránecká In Tille II/2 1937: 129-130)

Objevují se také varianty pohádky, které se od původního syžetu odlišují více. V jedné z nich vystupuje dívka, která vstoupila do služby k muži, jenž ji učil příst zlato z konopí. Dívka u něj byla nespokojená a žebrák jí poradil, že ji pán vyplatí jedině, když bude vědět, jak se jmenuje a z jaké kůže má boty. Dívka jednou slyšela pána si v noci pro sebe ř́kat: „Mé jméno je Tyngl a př́jmení Tangl, a mé boty jsou z bleší kůžičky, ze stehýnka." Vše mu zopakovala a on ji vyplatil a nechal jít (Hošek In Tille II/2 1937: 130). V tomto případě se pán podobně jako v předchozím vyprávění jmenuje Tyngl Tangl. 
V další odlišnějšś variantě získala dívka zlaté vlasy a vdala se za krále díky radě mužíka, jehož slyšela prozpěvovat si v lese. Měla propadnout do mužíkovy moci, pokud si nebude pamatovat jeho jméno, až ji po letech navštíví (zde je mužíkovo jméno Kulfáček). Před uplynutím doby, než měl mužík přijít, ho král slyšel prozpěvovat v lese: „Vař se polívčičko, breptej se hrášku, dobře, že to žádný neví, že mi ř́kají Kulfáčku“, a dívce tak jeho jméno připomněl (Dvořák č. 25 1984: 106-108).

Zaměříme-li se opět na standardní podobu vyprávění, lze zaznamenat několik vždy se opakujících motivů. Hlavní postavou je mladá dívka, s níž se ožení král, případně přislíbí, že se s ní ožení, pokud prokáže schopnosti, které ovšem dívka nemá. Vždy se objevuje motiv předení jako schopnosti, kterou má dívka ovládat (dokáže upříst velké množství materiálu / dokáže upř́íst materiál na zlato). Přijetí pomoci od mužíka je činem z nouze, protože jí hrozí smrt, a vždy ví také o ceně, kterou má za jeho pomoc zaplatit (prvorozené dítě / propadnutí do jeho moci). Všem vyprávěním je společný motiv uhodnutí jména mužíka, které se dívce podaří uhodnout na poslední chvíli, protože její manžel/sluha slyšel mužíka zpívat v lese písničku, v níž své jméno prozradí. To pak znamená osvobození jí nebo dítěte z mužíkovy moci. Patrně jde výhradně o motiv pohádkový, který se pojí s jediným syžetem.

\section{Prozrazení jména př́ibuzného}

Tabu jmenování př́íbuzného (Thompson C435. Tabu: uttering relative's name) se objevuje nejčastěji v konkrétní podobě tabu prozrazení jména nadpřirozené manželky (Thompson C435.1.1. Tabu: uttering name of supernatural wife). Thompson ve svém katalogu odkazuje např́klad na vyprávění z prostředí irského. V tradičním irském folkloru často vystupují tzv. fairies, bytosti s nadpřirozenými rysy, pro jejichž označení bylo obecně používáno mnoho eufemismů. V konkrétním vyprávění se lidský muž zamiloval do takové nadpřirozené ženy, která ho žádala, aby se o ní nikde nezmiňoval, nejmenoval ji. Muž se ovšem prořekl a žena byla donucena prozradit své jméno. To považovala za projev neúcty a od muže navždy odešla (Cross - Slover 1996: 208-210).

$\mathrm{Na}$ pohádky $\mathrm{v}$ podobném duchu lze narazit také $\mathrm{v}$ českém prostředí. Ve vyprávění z Podkrkonoší se muž oženil s vodní pannou, jíž musel slíbit, že ji neprozradí. Po nějaké době ale začal být v manželství nespokojený a slib porušil. Žena zmizela a vrátila se k muži až poté, co prochodil železné boty, které mu před svým odchodem dala (Kubín Podk. I č. 34 1964: 82-83). V několika dalších vyprávěních se jednalo o princeznu, kterou muž vysvobodil. Ta muže žádala, aby o ní nemluvil, když se rozhodl jet podívat 
domů. Muž slib porušil. Opět se objevuje motiv železných bot, které muž musí prochodit, aby se k němu žena vrátila (Dvořák č. 16 1984: 64-67; Kulda 1899: 319-321; Němcová I 1950: 23-32; srov. Tille II/1 1934: 357-368).

Zatímco v irském vyprávění byl odchod ženy poté, co byla donucena prozradit svou identitu, definitivní, v pohádkách českých zpravidla existuje v tomto typu vyprávění úkol, po jehož splnění se žena k muži vrátí. Pověsti o manželství s nadpřirozenou ženou, která požaduje určitou úctu, mají více podob. Žena nejčastěji žádá, aby na ni muž nebyl hrubý. Když muž slib poruší, navždy ho opustí (např. alpské pověsti [Röhrich 1976: 138], motiv se rovněž objevuje v pověstech českých [Grohmann č. 113 2009: 99]). Röhrich mluví o tomto motivu jako typickém pro prostředí staršího rolnického světa, v němž bylo bití žen patrně běžné (Röhrich 1976: 138).

\section{Prozrazení vlastní identity}

Tabu prozrazení vlastní identity (Thompson C436. Tabu: disclosing own identity. A supernatural person must not tell who he is) je motiv, na nějž lze narazit spíše v oblasti mytologické než folklorní. Proto jsou zde uvedené př́klady vybrány z tohoto materiálu a chybí vyprávění česká.

První př́klad, na nějž odkazuje také Thompson, se nachází v příbězích keltské irské mytologie. Je součástí cyklu mýtů o Kukulínovi (pův. Cú Chulainn), který určil, aby se za ním jeho syn Connla po určité době vypravil. Do té doby aby však skrýval své jméno a původ. Když se jeho syn objevil, dostali se spolu do sporu, a než mu stihl svou identitu prozradit, Kukulín ho zabil (Cross - Slover 1996: 172-175).

Motiv se nachází také v mytologii řecké. Když byl Odysseus se svými muži zajat kyklopem Polyfémem, řekl mu, že se jmenuje Nikdo. Následně obra oslepil, a když se druhové obra ptali, kdo mu to udělal, řekl, že Nikdo. Ostatní kyklopové tedy odešli a Odysseus mohl se zbývajícími muži slepému obrovi lstí uniknout (Homér 2018: 173-186). V tomto vyprávění má zatajení své identity jasně ochrannou funkci. V př́kladu prvním není explicitně řečeno, proč muselo k zatajení identity dojít. Podobný motiv, kdy zatajení identity způsobí smrt, se ovšem nachází v pohádkovém typu 939A Killing the Returned Soldier.

\section{Závěr}

Text představuje několik nejtypičtějších podob motivu tabuizovaného jména, které se objevují v českém a evropském, tradičním i současném, prozaickém folkloru.

Ze zde zmíněného výčtu je jasné, že motiv tabuizovaného jména není ojedinělým jevem a lze se s ním setkat na poli tradičního i současného 
folkloru. Lze o něm mluvit jako o jednom z mála motivů tabu s narativní funkcí, který je v této funkci zachován také ve folkloru současném. Většina ostatních podobných motivů se již dnes neobjevuje, protože byly spojeny především s komplexnějšími žánry, především pohádkami, jež současná doba již př́liš neprodukuje, naopak se zaměřuje na pověsti a žánry kratší, ve kterých pro tyto motivy není prostor. Funkce tabuizovaného jména se v různých narativech mění bez ohledu na folklorní žánr, od motivu, který je ústřední (např. pohádkový typ ATU 500, zmíněné současné pověsti), až po motiv pro vyprávění vedlejší a spíše doplňující.

Všechny rozebírané podoby tabuizovaného jména typické pro tradiční folklorní vyprávění zdůrazňují implicitní charakter tabu: že jméno démonické bytosti nesmí být tímto způsobem vysloveno, dotyčná osoba nemusí tušit, popř́padě nevěrí v platnost takového tabu, nebot jde většinou o přivolání neúmyslné. Zcela opačně fungují vyprávění z řad současných pověstí. $\mathrm{V}$ př́ipadě pověstí o vyvolávání duchů mrtvých je vždy jasné, že bude-li duch přivolán, stane se něco zlého. Proces jeho přivolání má jasně danou podobu: jde o konkrétní formuli či větu, kterou musí dotyčný pronést, popřípadě jde pouze o vyslovení jména (obvykle třikrát či pětkrát), na určitém místě a v určitém čase (v noci, před zrcadlem apod.). Vyvolávání duchů a s ním spojená tabuizace jejich jména má obecně blízko $\mathrm{k}$ tabu v jeho původním chápání. To zpravidla zahrnuje nadpřirozené prvky - trest za jejich porušení přináleží nějaké nadpřirozené síle, jež se vymyká lidskému řádu a která při porušení zcela nevyhnutelně prijide. Tato charakteristika tabu obecně vymizela. Lze-li v současnosti na tabu narazit, jsou to taková, jež př́mo porušují lidský trestní systém nebo překračují jistá společenská pravidla (nejedná se tedy již o tabu v klasickém slova smyslu, jeho obecně přijímaná definice se změnila). Potrestání za porušení je čistě v rukou lidské společnosti, magický atribut tabu mizí. Jednu z výjimek tvoři právě zde diskutované pověsti, protože trest za přivolání ducha přichází z jeho strany, stejně jako tomu bylo v uvedených pověstech tradičních $\mathrm{v}$ př́ípadě čerta nebo vodníka. V pověstech o vyvolávání duchů se také projevuje ambivalence, která je pro tabu typická. Je zde rozpor mezi strachem z porušení tabu a touhou tabu porušit. Tuto charakteristiku naopak postrádají varianty motivu popsané v pověstech tradičních. Dobrovolné vydávání se do nebezpečných situací i přes vědomí nevyhnutelného trestu a překračování hranic bez jakékoli jiné motivace, než je ověření jejich existence, poskytuje prostor pro ono vítězství touhy po odhalení tajemství nad strachem. Zároveň zde lze ale také pozorovat mnohem skeptičtější př́stup $\mathrm{k}$ tabu a především $\mathrm{k}$ nadpřirozenu (ačkoli ve zmíněných př́íkladech je jejich existence potvrzena), který je typičtější pro současné vnímání světa. 


\section{Bibliografie}

\section{Prameny}

Árnason, Jón. 2008. Mrtvému nože netřeba. Islandské povèsti a pohádky. Praha: Argo.

Cross, Tom P. - Slover, Clark H. 1996. Ancient Irish Tales. New York: Barnes \& Noble Books.

Dvořák, Karel. 2001. Nejstarši české pohádky. Praha: Argo.

Dvořák, Karel. 1984. Pohádky a pověsti našeho lidu. Praha: Odeon.

Grimm, Jacob - Grimm, Wilhelm. 1812. Kinder- und Hausmärchen. Band 1. Realschulbuchhandlung: Berlin.

Grohmann, Josef V. 2009. Pověsti z Čech. Praha: Plot.

Hazuka, V. - К̌epa, V. 1896. Pověsti jihočeské o strašidlech. Český lid 5, 3: 235-237.

Homér. 2018. Odyssea [online]. Městská knihovna v Praze. [21. 4. 2020]. Dostupné z https://web2.mlp.cz/koweb/00/04/43/08/91/odysseia. pdf.

Hošek, Ignác. 1897. Povídky z okolí svojanovského (ve vých. Čechách). Český lid 6, 2: 185-188.

Janeček, Petr. 2007. Černá sanitka: druhá žeň. Praha: Plot.

Janeček, Petr. 2015. Krvavá Máry a jiné strašidelné historky. Praha: Plot. Jech, Jaromír. 1959. Lidová vyprávění z Kladska. Praha: Státní nakladatelství krásné literatury, hudby a umění.

Koštál, Josef. 1892. Vodník v podání lidu českého. Český lid 1, 5: 468-472.

Kubín, Josef Š. 1908. Povídky kladské. Část 1. Praha: Společnost Národopisného muzea českoslovanského.

Kubín, Josef Š. 1910. Povídky kladské. Část 2. Praha: Společnost Národopisného muzea českoslovanského.

Kubín, Josef. Š. 1964. Lidové povídky z Podkrkonoší I. Praha: Státní nakladatelství krásné literatury a umění.

Kubín, Josef Š. 1971. Lidové povídky z Podkrkonoší II. Praha: Odeon.

Kulda, Beneš M. 1899. Moravské národní pohádky a pověsti z okolí sloupského. Českýlid 8, 5: 317-323.

Kulda, Beneš M. 1963. Pohádky a pověsti z Rožnovska. Praha: Státní nakladatelství krásné literatury a umění.

Němcová, Božena. 1950. Národní báchorky a pověsti I. Praha: Československý spisovatel.

Němcová, Božena. 1950. Národní báchorky a pověsti II. Praha: Československý spisovatel.

Polívka, Jiř́i. 1916. Povídky lidu opavského a hanáckého. Praha: Česká akademie císaře Františka Josefa pro vědy, slovesnost a umění. 
Röhrich, Lutz. 1966. Čert v pohádce a pověsti. Český lid 53, 1: 18-23. Sirovátka, Oldřich. 1959. Pohádky z Morary. Praha: Státní nakladatelství krásné literatury a umění.

Sosnovec, Josef. 1910. Šafář Chuchle a čert. Český lid 19, 9/10: 418-419. Zíbrt, Čeněk. 1924. Holánova pohádka o čertovi a Káči. Český lid 24, 10: 362-367.

\section{Literatura}

Clodd, Edward. 1898. Tom Tit Tot: An Essay on Savage Philosophy on Folk-tale. London: Duckworth and Co.

Dvořák, Karel. 2016. Soupis staročeských exempel. Praha: Argo.

Frazer, James G. 1994. Zlatá ratolest. Praha: Mladá fronta.

Freud, Sigmund. 1991. Totem a tabu. Praha: Práh.

Janyšková, Ilona. 2017. Tabu. In: Karlík, Petr - Nekula, Marek - Pleskalová, Jana (eds.): CzechEncy - Nový encyklopedický slovník češtiny [online]. [21. 4. 2020]. Dostupné z: https://www.czechency.org/slovnik/TABU.

Jech, Jaromír. 2008. Krakonoš. Praha: Plot.

Kraft, Hartmut. 2006. Tabu. Magie a sociální skutečnost. Praha: Mladá fronta.

Propp, Vladimir Jakovlevič. 1999. Morfologie pohádky a jiné studie. Praha: $\mathrm{H} \& \mathrm{H}$.

Röhrich, Lutz. 1976. Sage und Märchen. Freiburg im Breisgau: Herder.

Tille, Václav. 1929. Soupis českých pohádek. Svazek I. Praha: Česká akademie věd a umění.

Tille, Václav. 1934. Soupis českých pohádek. Svazek II/1. Praha: Česká akademie věd a umění.

Tille, Václav. 1937. Soupis českých pohádek. Svazek II/2. Praha: Česká akademie věd a umění.

Thompson, Stith. 1955. Motif-index of folk-literature: a classification of narrative elements in folktales, ballads, myths, fables, mediaeval romances, exempla, fabliaux, jest-books, and local legends. Bloomington: Indiana University Press.

Uther, Hans-Jörg. 2004. The Types of International Folktales. A Clasification and Bibliography. Based on the System of Antti Aarne and Stith Thompson. Helsinki: Academia Scientiarum Fennica. 